RASĀYAN J. Chem.

Vol. 13 | No. 1 |476 - 480| January - March | 2020 ISSN: 0974-1496 | e-ISSN: 0976-0083 | CODEN: RJCABP

\title{
PHYTOCHEMICAL SCREENING AND TOXICITY OF ETHANOLIC EXTRACT OF MANGROVE (Rhizophora mucronata) LEAVES FROM LANGSA, ACEH TIMUR
}

\author{
Gimelliya Saragih ${ }^{1,2, *}$, Tamrin ${ }^{1}$, Marpongahtun", Darwin Yunus Nasution' \\ and Abdillah ${ }^{2}$ \\ ${ }^{1}$ Department of Chemistry, Faculty of Mathematics and Natural Sciences, Universitas Sumatera \\ Utara, Medan, 20155, Indonesia \\ ${ }^{2}$ Department of Chemical Engineering, Politeknik Teknologi Kimia Industri, Jl. \\ Medan Tenggara VII, Medan 20228, Indonesia \\ *E-mail: thamrinsumut@gmail.com
}

\begin{abstract}
Mangrove has special properties, i.e. able to adapt to the extreme environment. Any kind of plant that able to adapt in such a condition usually can have a different metabolic pathway and as the impact, this plant can produce a different metabolite which can act as an antibiotic. The aim of this study was to evaluate the phytochemical content and toxicity properties of Rhizophora mucronata. The functional group that presence in the extract was determined using UV-Vis and FT-IR. The phytochemical screening showed the presence of alkaloid, flavonoid, quinone, tannin and phenolic. The UV-Vis spectrum also proved the presence of phenolic (tannin) and flavonoid in the Rhizophora mucronata extract (280-390 nm). The presence of hydroxyl, carboxylic acid, aromatic $\mathrm{C}=\mathrm{C}$ group was confirmed from the FTIR spectrum. The toxicity property of ethanolic extract of Rhizophora mucronata showed $\mathrm{LC}_{50}$ of $636.73 \mathrm{ppm} \leq 1000 \mathrm{mg} / \mathrm{L}$.

Keywords: Mangrove, Rhizophora mucronata, Phytochemical, FTIR, UV-Vis, Toxicity
\end{abstract}

(c) RASĀYAN. All rights reserved

\section{INTRODUCTION}

Mangrove is plant communities that grow in coastal saline or brackish water and functioned as protectors of the coastal area from erosion, storm sturge and tsunami. Langsa is a city in Aceh province with 262.41 $\mathrm{km}^{2}$ of area. The mangroves in-and-around the langsa city have decreased in the area from $9550 \mathrm{ha}$ in 2013 to 7837 ha as of 2015, during this time commercial shrimp aquaculture has become the dominant land-cover within this estuary environment. ${ }^{1}$

In Aceh, mangrove leaves have been utilized as a traditional medicine to cure several health issues, such as dysentery, bleeding, weight loss, antiseptic.

Mangrove plant has special ability to able to grow in an extreme environment, i.e. waterlogging, unstable and oxygen-deficient soils, and high salinity. ${ }^{2}$ Any kind of plant that able to cope with this condition, usually will be able to have a new metabolic pathway and produce a specific metabolite that can be utilized to support its life. ${ }^{3}$ From the previous study, mangrove plants consisted of several secondary metabolites, such as alkaloid, saponin, tannin, and flavonoid. The presence of these metabolites can be used as an indication of the potency of mangrove as a medicine plant. ${ }^{4}$ Based on previous research, mangrove extract showed a potency as antimicrobe, antivirus, anticancer, and antidiabetic. ${ }^{5}$

The phytochemical screening and toxicity properties are common methods that can be used to discover new kinds of medicine. Toxicity is a degree to indicate which substance or chemical that can harm humans or animals. BSLT technique is a common method that can be used to identify the toxicity property of any chemical.

The objective of the current research was to identify the phytochemical content and the toxicity properties of ethanolic extract of Rhizophora mucronata from Langsa, Aceh Timur.

Rasayan J. Chem., 13(1), 476-480(2020)

http://dx.doi.org/10.31788/RJC.2020.1315524

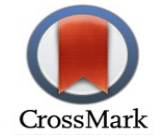


RASĀYAN J. Chem.

Vol. 13 | No. 1 |476 - 480| January - March | 2020

\section{Material and Method}

\section{EXPERIMENTAL}

Rhizophora mucronata leaves were collected from mangrove forest in Langsa, Aceh Timur. The obtained leaves were air-dried until the water content was $\pm 15 \%$. The taxonomy of this plant was identified in Herbarium medanense (MEDA), Universitas Sumatera Utara, Indonesia.

\section{General Procedure}

The extraction process of Rhizophora mucronata was performed following the maceration technique of Baehaki Ace, 2017. ${ }^{6}$ The dried leaves were grounded to obtain powder formed. About $20 \mathrm{~g}$ of simplisia was macerated using $80 \mathrm{~mL}$ of $95 \%$ ethanol for $24 \mathrm{~h}$ while shaking in a shaker. The mixture was filtrated using Whatman No. 42. The obtained filtrate was then evaporated using a rotary evaporator until the concentrated extract was obtained. This extract was characterized for phytochemical screening, UV-Vis, FTIR and toxicity

\section{Detection Method}

Phytochemical Screening

The qualitative phytochemical screening of Rhizophora mucronata extract was performed using Harborne $^{7}$ and Trease \& Evans method. ${ }^{8}$

\section{UV-Visible Spectrophotometer}

The spectrum of a single eluted compound was further recorded between 280 to $450 \mathrm{~nm}$ on a UV-Visible Spectrophotometer (Thermo Scientific Inc., MA, and USA)

\section{Fourier Transform Infrared Spectroscopy (FTIR)}

The FTIR spectrum of the sample was recorded using a Bruker OPUS 7.5.18 infrared spectrometer (Bruker, Germany) at wavelengths from 400 to $4000 \mathrm{~cm}^{-1}$ at a speed of $20 \mathrm{~cm}^{-1} . \mathrm{s}^{1}$

\section{BSLT}

The toxicity of Rhizophora mucronata was evaluated using BSLT method. About 10 larvae of A. salina Leach that has been growing for $48 \mathrm{~h}$ was placed into a bottle that contained seawater and extract. The BSLT was performed triplicate for each group and observed for $24 \mathrm{~h}$. The number of dead larvae was calculated, and the percentage of mortality was calculated. The obtained data were used to determine the $\mathrm{LC}_{50}$.

\section{Phytochemical Screening}

\section{RESULTS AND DISCUSSION}

The phytochemical screening showed Rhizophora mucronata leaves that extracted using $96 \%$ ethanol consisted of several secondary metabolites, i.e. alkaloid, flavonoid, quinone, tannine, and phenolic. Phytochemical content in plants has a significant role in the antibacterial activity. ${ }^{9}$ Apart from that, plants that are composed of bioactive compounds such as flavonoids, alkaloids, saponins, phenolic vitamins, etc. also have biochemical activity. ${ }^{10}$ The screening result of Rhizophora mucronata leaves extract was shown in Table-1.

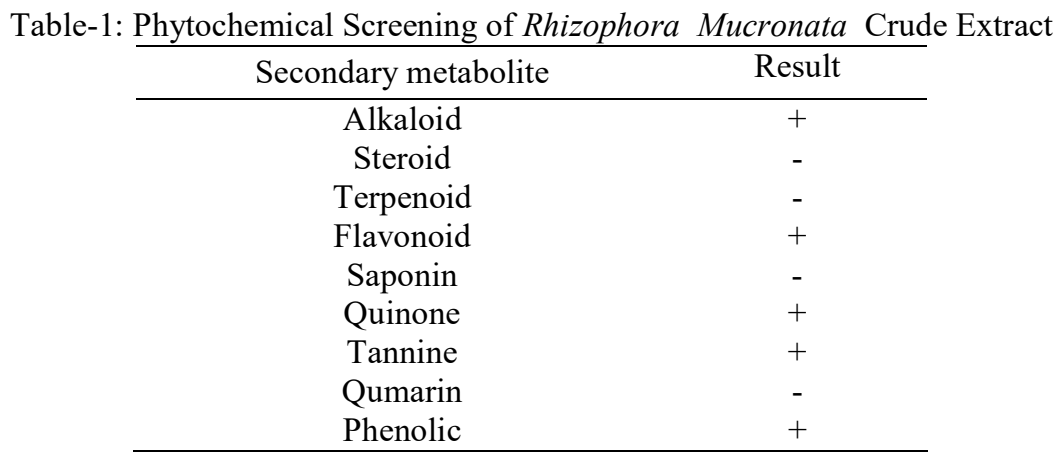


RASĀYAN J. Chem.

Vol. 13 | No. 1 |476 - 480| January - March | 2020

The presence of those metabolites can indicate a potency of Rhizophora mucronata as a new potential medicine. In the previous study, those metabolics can be used as an antibacterial agent that works in different ways. Alkaloid was identified can act as an interfere to disturb the formation of the cell wall and induced the dead cell. Flavonoid is a lypophilic compound that can easily interact with the phospholipid that can be found in the bacterial cell wall, as a result, the flavonoid can act as antibacterial.

Tannin has potency as a chelating agent with plasmolytic affect and disturbs the cell permeability. Tannin can as an antibacterial agent through protein precipitation, interact with the cell membrane, enzyme inactivation, destruction or inactivation of bacterial genetic material. ${ }^{11}$ The antimutagenic activity of plants is due to the presence of total phenols and flavonoid content. ${ }^{12}$

\section{UV-Visible Spectrophotometer}

The UV-Vis spectrum of Rhizophora mucronata leaves extract is shown in Fig-1 that measured in the range $260-450 \mathrm{~nm}$. The highest peak is observed at $288 \mathrm{~nm}$ with a value of 0.173 . This result showed the presence of flavonoids in the extract.

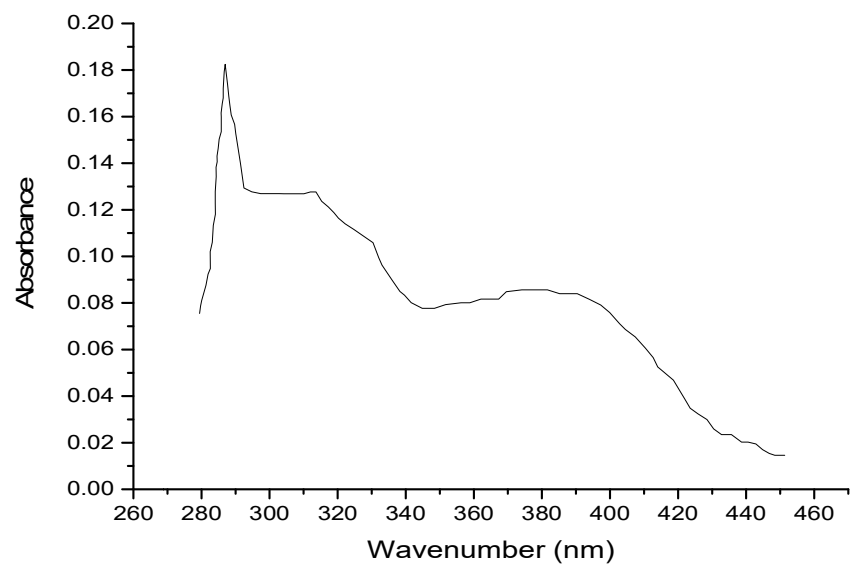

Fig-1: UV-Vis Spectrum of Rhizophora Mucronata Leaves Extract

Flavonoid has a specific peak around $240-290 \mathrm{~nm}$, this wide range is caused by the presence of conjugation bonding of ring structure. ${ }^{13-14}$

\section{FTIR Analysis}

The FTIR analysis was performed to determine the functional group that presence in the ethanolic extract of Rhizophora mucronata leaves. The FTIR spectrum of the Rhizophora mucronata is shown in Fig-2.

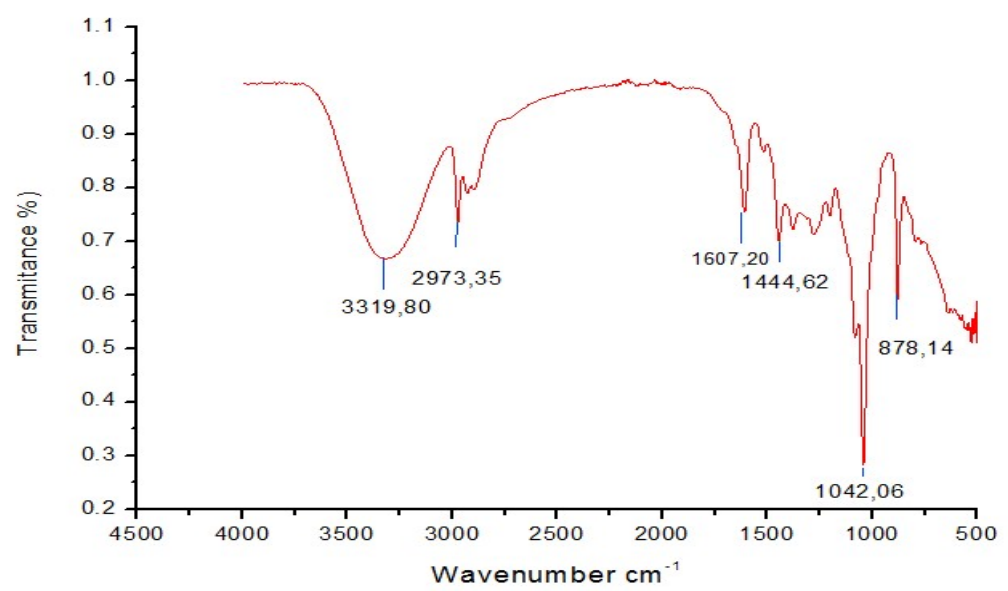

Fig-2: FTIR Spectrum of Rhizophora Mucronata Leaves Extract 


\section{RASĀYAN J. Chem.}

Vol. 13 | No. 1 |476 - 480| January - March | 2020

The FTIR spectrum showed the presence of a typical peak of flavonoid, i.e. $3319,2973,1607,1444$, 1042 , and $878 \mathrm{~cm}^{-1}$. The band at 3319 is assigned to the presence of $-\mathrm{OH}$ stretching from phenolic. The presence of $\mathrm{C}-\mathrm{H}$ alkena is assigned by the band at $2973 \mathrm{~cm}^{-1}$. While band at 1607 and $878 \mathrm{~cm}^{-1}$ are indicated to the presence of $\mathrm{C}=\mathrm{C}$ from aromatic ring and $\mathrm{C}-\mathrm{O} .{ }^{15}$

\section{BSLT (Brine Shrimp Lethality Test)}

The toxicity of Rhizophora mucronata was determined using BSLT method. The mortality percentage and $\mathrm{LC}_{50}$ of ethanolic extract of Rhizophora mucronata are shown in Table-2.

\begin{tabular}{|c|c|c|c|c|}
\hline $\begin{array}{l}\text { Concentration } \\
\text { (ppm) }\end{array}$ & Dead & Larvae total & $\begin{array}{c}\text { Motality } \\
(\%)\end{array}$ & $\begin{array}{l}\mathrm{LC}_{50} \\
(\mathrm{ppm})\end{array}$ \\
\hline 10 & 5 & 30 & 16,66 & \\
\hline 100 & 7 & 30 & 23,33 & 636,725 \\
\hline 1000 & 21 & 30 & 70,00 & \\
\hline
\end{tabular}

Based on $\mathrm{LC}_{50}$ value, the ethanolic extract of Rhizophora mucronata is classified has moderate toxicity. Meyer et $\mathrm{al}^{16}$ in his study classified the toxicity of substance or chemical based on the concentration, i.e. $\leq 30 \mathrm{mg} / \mathrm{L}=$ very toxic, $\mathrm{LC}_{50} \leq 1000 \mathrm{mg} / \mathrm{L}=$ moderate, $\mathrm{LC}_{50}>1000 \mathrm{mg} / \mathrm{L}=$ not toxic. $\mathrm{LC}_{50}$ is calculated by determining the concentration of test compounds that can kill $50 \%$ population of shrimp larvae ${ }^{17}$.

\section{CONCLUSION}

The phytochemical screening of ethanolic extract of Rhizophora mucronata identified the presence of flavonoid, alkaloid, tannin, phenolic and quinone. The BSLT test showed that the ethanolic extract of Rhizophora mucronata has moderate toxicity.

\section{ACKNOWLEDGMENT}

The authors are grateful to the Badan Pengembangan Sumber Daya Manusia Industri Ministry of Industry who has supported the funding of this research, Politeknik Teknologi Kimia Industri Medan, Department of Chemistry, Universitas Sumatera Utara, Medan for its support in the use of laboratories.

\section{REFERENCES}

1. D. Setiawan and A. Zaitunah, Peronema Forestry Science Journal, 5(1), 191 (2016).

2. Febriandi, Sumatra Journal of Disaster, Geography and Geography Education, 1(1), 105 (2017).

3. F. Ahmed, S. Kumar and T.A. Apoptosis, The Japanese Society of Pharmacognosy and Springer, 64, 393 (2010), DOI: 10.1007/s11418-010-0424-7

4. E. A. B. Edu, N. L. Edwin-Wosu and O. U. Udensi, Journal of Natural Sciences Research, 5(23), 1 (2015).

5. P. Saranraj and D. Sujitha, American-Eurasian Journal of Toxicological Sciences, 7(3), 146 (2015), DOI: 10.5829/idosi.aejts.2015.7.3.94150

6. A. Baehaki, I. Widiastuti and N. Jannah, Oriental Journal Of Chemistry, 33(1), 181 (2017), DOI: $10.13005 / \mathrm{ojc} / 330120$

7. J. B. Harborne, Phytochemical methods: A Guide to Modern Techniques of Plant Analysis. 2nd edn, Chapman and Hall, New York, pp. 88,185 (1973).

8. G.E. Trease, W.C. Evans, Textbook of Pharmacognosy. 12th edn. Balliese Tindall and Company Publisher, London, pp. 343, 383(1983).

9. D. U. C. Rahayu, Hartono and P. Sugita, Rasayan Journal of Chemistry, 11(2), 762 (2018), DOI: $10.7324 /$ RJC.2018.1122076

10. R. Hardiyanti, L. Marpaung, I. K. Adnyana and P. Simanjuntak, Rasayan Journal of Chemistry, 12(4), 1822 (2019), DOI:10.31788/RJC.2019.1235353

11. A. Poedjiadi and F.T. Supriyanti, Dasar-Dasar Biokimia: UI-Press , Jakarta (2012).

ETHANOLIC EXTRACT OF MANGROVE 
RASĀYAN J. Chem.

Vol. 13 | No. 1 |476 - 480| January - March | 2020

12. Sumaiyah, Masfria and A. Dalimunthe, Rasayan Journal of Chemistry, 11(2), 505 (2018), DOI: $10.7324 /$ RJC.2018.1122068

13. S. Kumar and A. K. Pandey, The Scientific World Journal, 2013, 01 (2013), DOI: $10.1155 / 2013 / 162750$

14. T. T. Kumar, S. M. Salique, M. Hussain, M. Ilyas, N. Thajuddin and H.S. Jahangir, Pharmacognosy Journal, 10(6), 1208 (2018), DOI:10.5530/pj.2018.6.207

15. S. Arunprabu, P. Dinesh and T. Ramanathan, International Journal of Science Iventions Today, 5(6), 520 (2016),

16. J. L. Meyer, B. N., Ferrigni, N. R., Putnam, J. E., Jacobsen, L. B., Nichols and D.E.McLaughlin, Planta Medica, 45, 31 (1982), DOI:10.1055/s-2007-971236

17. I. D. Riris, M. Simorangkir and A. Silalahi, Rasayan Journal of Chemistry, 11(3), 1229 (2018), DOI: 10.31788/RJC.2018.1133090

[RJC-5524/2019] 